\title{
Understanding perceptions of fresh produce safety and barriers to Good Agricultural Practices (GAP) use among Amish growers in the Holmes County Settlement of Ohio
}

\author{
Jason Shaw Parker ${ }^{\text {* }}$ \\ University of Vermont \\ Pamela Schlegel, ${ }^{b}$ Douglas Doohan, ${ }^{c}$ and Jeffrey T. LeJeune ${ }^{b}$ \\ The Ohio State University
}

\begin{abstract}
Submitted June 13, 2014 / Revised June 24, 2014; June 16, September 21, and December 13, 2015; and February 3, 2016 / Accepted January 9, 2016 / Published online June 13, 2016

Citation: Parker, J. S., Schlegel, P., Doohan, D., \& LeJeune, J. T. (2016). Understanding perceptions of fresh produce safety and barriers to Good Agricultural Practices (GAP) use among Amish growers in the Holmes County Settlement of Ohio. Journal of Agriculture, Food Systems, and Community Development, 6(3), 37-59. http://dx.doi.org/10.5304/jafscd.2016.063.006

Copyright (C) 2016 by New Leaf Associates, Inc.
\end{abstract}

\begin{abstract}
Addressing the complex problem of ensuring onfarm produce safety entails processes that allow for participation of affected groups, and integration of their knowledge and perceptions into the solutions. Such participatory processes, however, are difficult to develop among underserved groups, like the Amish communities of Ohio, where members seek

a * Corresponding author: Jason Shaw Parker, Plant and Soil Science, University of Vermont; 202 Jeffords Hall; Burlington, Vermont 05401 USA; +1-802-656-2824; jparker7@uvm.edu

b Food and Animal Health Research Project, Ohio

Agricultural Research and Development Center.

${ }^{c}$ Horticulture and Crop Science, Ohio Agricultural Research and Development Center, The Ohio State University.
\end{abstract}

\section{Disclosure}

This project was funded through the U.S. Department of Agriculture, National Institute of Food and Agriculture [USDA NIFA] National Integrated Food Safety Initiative, project \#2007-51110-03817. deliberate separation from mainstream society and have insular social networks and limited trust in government agents. Using a mental models framework, we present research findings that will be used to help develop an outreach program to address produce safety in Amish communities in Ohio. These findings expand our understandings of Amish growers' perceptions and knowledge of on-farm produce safety practices in the following areas: the microbial risks to fresh and fresh-cut produce; practices that can prevent contamination; perceptions of the economic feasibility of adopting these practices; preparedness for a contamination event; and information needs and preferences.

Information was collected to aid the development of outreach that respects the values and goals of the Amish produce growers, which is a key factor for program success, and that encourages the adoption of food safety principles in scaleappropriate ways by addressing barriers and building rapport and trust with community 
members. We believe that the information learned in this study is useful to a variety of people working with Plain Communities and other nonmechanized, small-scale farmers in addition to these communities.

\section{Keywords}

food safety, Amish, Plain Communities, fresh produce, small-scale farms, underserved groups

\section{Introduction}

Many Amish communities are experiencing extensive demographic and social change associated with increased population (Donnermeyer, Anderson, \& Cooksey, 2013), historically low commodity milk prices, increased feed costs, and land scarcity in settlements near larger urban areas. This is the case for the Holmes County Amish settlement near the Cleveland-Akron metropolitan area. Over the last two decades, Ohio Amish communities have adopted strategies to deal with these changes. These strategies include intensification and specialization of farming (Long, 2003) and continued diversification by adding or expanding produce to their list of farm products (Parker, 2006). For these new or beginning produce growers, the small scale of most Amish operations will likely exempt them from regulations created under the Food Safety Modernization Act (FSMA). (Those Amish who market through local auction houses or who grow non-exempt products, however, will likely be required to have GAP certification.) Indeed, among new and beginning Amish growers, produce production is seen as an affordable entry into farming because land and input costs for expanding or start-up are low (Weaver, personal communication, 2010). Assuming these growers have reliable produce safety information is difficult because Amish intentionally live separately from mainstream American society and have a contested history of negotiated legal and socio-cultural behaviors and separations on issues involving government mandates and regulations (e.g., Social Security, compulsory military service, public schooling) that have paradoxically accompanied increasing economic integration. These conflicting values of socio-cultural separation and federal oversight create tensions when policy-makers seek consumer protections through governmentmandated programs. The expansion of produce production in Amish communities increases the need for food systems professionals to understand the food-safety information needs of this unique population of growers.

Evaluating the adoption of new ideas and technologies in similar farming communities is important to understanding their effects. Extension professionals describe Amish communities as underserved (Hoorman \& Spencer, 2001), a designation related to Extension offering fewer programs that serve them compared to other communities. Conversely, there are fewer Amish growers than those from other communities seeking programming from Extension professionals. The characteristics of both the message and the messenger in the dissemination of knowledge are important to the diffusion of innovations (Brown, 1981; Wejnert, 2002) and are critical considerations when dealing with any underrepresented community such as the Ohio Amish. This paper presents a subset of findings from data collected among Amish produce growers in the Holmes County Settlement, Ohio, as part of a 2011 study to better understand the range of food safety perceptions and beliefs. The project aimed to understand produce grower perceptions and beliefs of contamination sources and prevention practices across a variety of grower groups that included growers of small, medium, and large farms and two underserved grower populations, Amish and African Americans. Our goal in this paper is to identify educational needs in order to enhance Amish growers' understanding and capacity to fulfill market demands for safe food with culturally and technologically appropriate practices. This project expands understandings of Amish growers' perceptions and beliefs in the following areas: the microbial risks to fresh and fresh-cut produce; practices that can prevent contamination; perceptions of the economic feasibility of adopting these practices; preparedness for a contamination event; and information needs and preferences. Findings from this study provide information to aid the development of outreach efforts to both support the values and goals of the Amish produce growers and encourage the adoption of produce safety 
principles. The scale-appropriateness of practices is emphasized to address grower concerns for food safety regulations, address real and perceived barriers, and build rapport and trust with Amish and other underserved communities. These latter three points are important to enhancing or creating successful engagement with Amish communities. Finally, a program of the local auction house, the Grower's Code of Excellence, is identified as a potential model for collaboration with members of the Amish community to develop a locally supported and technology- and scale-appropriate produce grower safety program. While the specific characteristics of community organization and perceptions and beliefs of community members may vary among stakeholders, the lessons learned from this study can be applied to assist other smallscale farmers outside the Plain Community. ${ }^{1}$

\section{Background}

While adhering to tradition, many members of Amish communities are viewed as entrepreneurial and inventive, even looking forward and cautiously anticipating change that allows them to explore potential impacts of new behaviors and technologies (Landing, 1970; Lowry \& Noble, 2000). As one Amish farm implement dealer and respected community leader stated, "The Amish do not fear modern technology; they chose not to be controlled by it" (Parker, 2013, p. 163). Traditional Amish household livelihoods include production of diverse farm products and income sources derived from low-input, intensive practices that include small fields, multiple crops, multiyear rotations, and several cottage industries. Other characteristics include the use of animal traction as their power source, reliance on animal manure fertilizers, a well-balanced ratio of acres farmed to animal numbers, and the use of local ecological indicators for planting and harvesting times (Kline, 1990; Moore, 1995; Moore, Stinner, Kline, \& Kline, 2000). Yet social and economic pressures of the last three decades, such as the increasing

\footnotetext{
${ }^{1}$ Plain Communities are affiliations of Anabaptist Christians, whose lifeways minimize hierarchy and emphasize living separately from the world, living plainly in technology and dress, and value community over the individual. The extent to
}

population in their communities (Donnermeyer et al., 2013), increased herd sizes and the resulting reliance on external feed sources (Bender, 2003), low commodity milk prices, and both a decreasing availability and increasing costs of agricultural land, have attracted established and beginning Amish growers to higher cash returns available from fresh produce production (Parker, 2013).

While the Amish are a patriarchal society, they seek nonhierarchical community outside of the household and family. Members of Amish communities affiliate through Church Districts (CD), each consisting of 20 to 30 families with their own set of rules for living, called an Ordnung, and leadership (ministers and bishops) chosen by lottery. The cultural and religious similarities across CDs, such as interpretations of doctrine, dress, and behavior (including use of technology), further aggregate Amish households into Orders that are determined by the degree of adherence to tradition (for a detailed discussion of tradition, see also Parker, 2013). In the Holmes County Settlement, these socio-spatial groupings often cluster around valleys, establishing communities within subwatershed boundaries (Parker, 2006). Church Districts of multiple Orders are spatially grouped, forming settlements such as the Holmes County Settlement in Ohio or the Elkhart-LaGrange Settlement in Indiana.

The socio-cultural data collected in this study are necessary to understand Amish farming systems and decision-making processes at the household and community levels, which are valuable for enhancing outreach programs. Many Amish in the Holmes County Settlement sell through local auction houses, making it necessary that they comply with FSMA produce safety rules. There are 66 such auction houses across the Midwestern U.S. that serve mostly Amish and Mennonite growers. They range in size from smaller auctions of 50 growers to 600 growers at some larger auctions. Yoder (2009) estimates that 20,000 families are supported by selling produce at auction houses.

which these ideas are acted on and practiced in daily life varies across groups. Some notable Plain Communities include various affiliates of Amish, Mennonite, Hutterite, and Brethren. 
The Mount Hope Auction House where most growers in this research sell their produce has a voluntary program called the Growers' Code of Excellence. Those who comply with the program standards are permitted to use the auction house's Seal of Quality label on their produce. The criteria for this program include:

- Use the Auction House Farm Production Record Book (FPRB).

- Keep accurate records of growing, harvesting, packing, and sanitation practices in the FPRB.

- Keep a copy of current coliform water test in the FPRB.

- Attend grower education meetings at the Auction House.

- Follow an Integrated Pest Management (IPM) program.

- Keep pesticide spray records as required by law (e.g., follow the Ohio Vegetable Production manual).

- Apply manure to fields no sooner than 90 days before planting any produce crops (with some exceptions), and maintain records in the FPRB.

- Attend GAP meetings and practice GAP requirements on the farm.

- Agree to inspection of the farm's facilities and FPRB by Auction House staff.

- Apply Seal of Quality stickers or grower produce number on each unit of Grade 1 produce. (Mount Hope Auction House, n.d.)

\section{Applied Research Methods}

We used a modified mental models approach guided by the Expert Model of Fresh and Fresh Cut Produce Food Safety ${ }^{2}$ (Parker, Wilson, Rivers, LeJeune, \& Doohan, 2012a) that outlines expert perceptions of influences shaping grower decisionmaking. This model, consisting of input from scientists, educators, farmers, and policy-makers, shaped our program development and analysis on the range of perceptions for produce safety in this

${ }^{2}$ Developed by the authors using the input from food safety experts participating in a 2007 symposium and workshop on
Amish community. Knowing the content of this range will better facilitate engaging with community members, understanding their perspectives, and providing content to reshape produce safety attitudes and beliefs.

Guided by the widely used risk analysis and mental models approach (Atman, Bostrom, Fischoff, \& Morgan, 1994; Bostrom, Fischoff, \& Morgan, 1992; Fischhoff, Bostrom, \& Quadrel, 1997; Johnson-Laird, 1983; Morgan, Fischoff, Bostyrom, \& Atman, 2002), this research used a multistage methodology to assess Amish produce growers' perceptions and beliefs of on-farm produce safety. The expert model outlined important content areas that were aligned with GAP certification criteria for on-farm food safety and the influences that shape farmer decision-making. The mental model stages included (1) the development of the expert model and its dissemination to other experts for input and refinement. Using this model, we (2) developed an interview protocol that was tested with small-scale Amish and African American growers as well as growers representative of other Midwestern farm sizes. The final stages of the research were (3) to develop and test educational tools for working with Amish communities, and (4) disseminate the results through educational programs and risk-based messaging. These include tools that can enhance the ability of food systems professionals to engage Amish communities in salient food safety education. Our findings identified the need for scale-appropriate recommendations that Extension could offer to growers using preferred channels in order to enhance better dissemination and adoption (Kline, Keen, Barrett, Kleinschmidt, \& Doohan, 2012).

Our modification of Morgan et al.'s (2002) mental models framework included the following: We incorporated participant observation at the auction house in which at least two team members spent additional time observing and interacting with Amish produce growers. These visits were focused on understanding the practices that auction house staff and farmers used that could ensure the safety of produce through the auction

the topic (Parker et al., 2012a). 
house chain of custody. This information was used to improve our understanding of the relationship and interactions among auction house staff with growers and its role as a community institution. Informal interviews were conducted with community leaders, agricultural suppliers, and Amish growers and staff at the auction house. The final modification of the methodology was to make the process reflexive. That is, most risk analysis uses an elite-driven approach where expert knowledge is privileged over practitioners' knowledge, and gaps in practitioner knowledge become the focus of analysis. In this research, we enhanced the expert knowledge with what was learned from practitioners to provide feedback in our model design.

Twelve mental models interviews were conducted with Amish household members in the Holmes County Settlement using a judgment sample. The sample was created in consultation with local Amish leaders, Amish farm suppliers, and Extension agents who recommended growers based on the following farmer and farm characteristics:

- Amish produce growers;

- Farm development stages: beginning, poststartup, established (Sheils, 2002); and

- Participation, or not, at produce grower meetings with a produce auction house.

We began our sample with a short list of four Amish growers, suggested by local Amish agricultural supply dealers with a shared rapport. Some of these growers market their produce at the local Mount Hope Auction House. Additionally, candidates were identified through a snowball sample of participating growers who referred an additional eight growers with characteristics matching our criteria. Parallel to the experiences reported by Guest, Bunce, and Johnson (2006), data saturation occurred in 12 interviews, which we believe to be representative given our collective experience working in the community, the acute domain of analysis, and the relative homogeneity of this Amish society. The duration of the interviews ranged from 45 to 70 minutes, with an average time of 60 minutes. Unlike the other 50 interviews with growers from small, medium, and large-scale farms in Ohio and Indiana as well as very small- scale African American growers in Kentucky, these interviews used no recording devices and instead relied on handwritten notes that were later transcribed for coding.

Using a semistructured interview format, participants were encouraged to expand on the following six areas: (1) farm and farmer background; (2) pre- and post-harvest sources of contamination; (3) contamination prevention practices; (4) perceptions of the economic feasibility of prevention practices, and preparedness for a food safety incident; (5) information preferences and needs; and (6) grower demographics and farm structure. Each participant was asked the same questions with scripted followup prompts offered for respondents when elicited answers did not provide enough information on the topic. Table 1 lists the content areas covered for each category.

The information obtained during these interviews was discussed among the members of the research group, who together have over 30 years of experience working in Amish and other small-scale farming communities. This background of working with Amish growers provided additional basis for observation and framing of research findings. Because produce safety risks come from pathogens and chemical sources, we use the term "contamination" to refer to introduction or spread of these sources of foodborne illness.

\section{Study Limitations}

There are limitations to this study related to unique considerations that are needed for conducting interviews and questionnaire surveys in Amish communities. While there is much similarity across Amish Settlements and among the Orders within Settlements, the data and experiences shared in this paper are drawn from one Settlement and explore the range of thinking about produce safety among the New Order and Old Order Amish only. The views of those interviewed and other groups, like the more traditional Swartzentruber Amish who declined to be interviewed, may differ. Practitioners may note other differences exist across Settlements inspiring opportunities for further research.

Many Amish growers in the study Settlement found it uncomfortable to rank-order phenomena 
particularly related to other people, which is a cultural barrier to survey methods that has been encountered in other research. The interview format provided us the opportunity to work with participants to improve the validity of responses. Several participants perceived the labels of "labor," "workers," and "employees" as too abstract, or were uncomfortable using them to refer to people

\section{Table 1. Interview Content Areas and Question Topics}

\begin{tabular}{|c|c|c|}
\hline Question Category & Relevant Question Subject Areas & Examples of Question Topics* \\
\hline Farm Information & $\begin{array}{l}\text { - Description of farm size, type, } \\
\text { produce grown, number of } \\
\text { workers } \\
\text { - Role of workers on the farm }\end{array}$ & $\begin{array}{l}\text { - Please tell me about your farming operation. } \\
\text { - What are your goals for the farm? How do you } \\
\text { define success? } \\
\text { What are the roles people have on your farm? What } \\
\text { work needs done and who does it? }\end{array}$ \\
\hline Contamination Sources & $\begin{array}{l}\text { - Pre-harvest contamination } \\
\text { sources } \\
\text { - Post-harvest contamination } \\
\text { sources }\end{array}$ & $\begin{array}{l}\text { - Types of produce safety concerns faced by farmer } \\
\text { (bacterial, viral, or chemical, with specific prompts } \\
\text { for melons, tomatoes, leafy greens). } \\
\text { - Water sources for rinsing, washing, or irrigation, } \\
\text { types of irrigation used. } \\
\text { - Use of manure and compost. } \\
\text { - Use of animals in farming. } \\
\text { - Facilities and farm equipment. } \\
\text { - Worker and other people (e.g., customers) sources } \\
\text { of contamination. }\end{array}$ \\
\hline Prevention Practices & $\begin{array}{l}\text { - Prevention practices that mini- } \\
\text { mize contamination }\end{array}$ & $\begin{array}{l}\text { - Types of prevention activities used or available for } \\
\text { each of the above topics and perceptions of } \\
\text { practice effectiveness. }\end{array}$ \\
\hline $\begin{array}{l}\text { Barriers to Adoption \& } \\
\text { Preparedness }\end{array}$ & $\begin{array}{l}\text { - Perceived economic feasibility } \\
\text { of prevention practices } \\
\text { - Level of preparedness for deal- } \\
\text { ing with an on-farm outbreak }\end{array}$ & $\begin{array}{l}\text { - Barriers, real and perceived, that prevent growers } \\
\text { from adopting specific prevention practices. } \\
\text { - Barriers can be social, economic, physical, } \\
\text { technological, etc. } \\
\text { - Self-assessment of preparedness for dealing with a } \\
\text { foodborne illness outbreak. }\end{array}$ \\
\hline Information Preferences & $\begin{array}{l}\text { - Information channel prefer- } \\
\text { ences for: Farming, produce } \\
\text { safety, and dealing with an } \\
\text { immediate outbreak }\end{array}$ & $\begin{array}{l}\text { - Preferences for sources of information (e.g., } \\
\text { industry, experience and testimonial, scientific, trial } \\
\text { and error). } \\
\text { - Preferences for channels of information (e.g., } \\
\text { Extension, friends and family, print media, } \\
\text { seminars, consultants). } \\
\text { - Differences between preferences based on general } \\
\text { information seeking versus produce safety } \\
\text { information seeking. } \\
\text { - Current produce safety information needs. }\end{array}$ \\
\hline $\begin{array}{l}\text { Farm Information \& } \\
\text { Respondent } \\
\text { Demographics }\end{array}$ & $\begin{array}{l}\text { - Age } \\
\text { - Sex } \\
\text { - Farm income-farm scale } \\
\text { - Acres farmed-farm scale } \\
\text { - Number of Workers } \\
\text { - Years Farming }\end{array}$ & $\begin{array}{l}\text { - Age and sex of respondent. } \\
\text { - Farm income ranges based on USDA income-based } \\
\text { farm size (less than US } \$ 250,000=\text { small; } \\
\text { US } \$ 250,000 \text { to US } \$ 500,000=\text { medium; greater } \\
\text { than US } \$ 500,000=\text { large). } \\
\text { - Number of owned and leased acres farmed in the } \\
\text { current growing season (there is one growing } \\
\text { season in Ohio). } \\
\text { - The number of family and non-family workers, full } \\
\text { and part time status, and the duties they perform. } \\
\text { - Total number of years of farming experience } \\
\text { (apprentice and operator years included). }\end{array}$ \\
\hline
\end{tabular}

\footnotetext{
* A full list of questions in each category is available from the author.
} 
who were mostly family members. It is also possible that the aversion to these labels was to avoid potential legal issues or because of a lack of familiarity with employee hiring categories and farm labor. While there is little likelihood that this interfered with data collection, it was mentioned often enough to be consideration for future work in this community. Due to the generally quiet and modest mannerisms of most Amish growers, their responses can appear understated. This was addressed by using probing or follow-up questions. Responses were interpreted within this context using this cultural knowledge. These limitations are taken as additional data and insights in our analysis and findings.

\section{Results}

\section{Amish Farm Types, Goals, and Values}

Amish growers raise a very diverse mix of fresh produce and rarely specialize in one type. Most Amish growers do not participate in the USDA Census of Agriculture, so an exact quantification of this diversity is not currently possible. Produce grown by interviewees is typically sold fresh and includes sweet corn, cantaloupes, cabbage, broccoli, onions, strawberries, leafy greens, zucchini, cucumbers, green beans, squash, eggplant, potatoes, tomatoes, and peppers. Less than 20 percent of participants reported being USDA Certified Organic. The average farm is 60 acres $(24.3 \mathrm{hec}-$ tares), reports less than US $\$ 100,000$ in gross sales, and has 7 workers (mostly related household members). The average Amish grower in this study is 45 years of age with 9 years of produce-growing experience, indicating a relatively young cohort of late-entry or expanding produce growers (Table 2). All interviewees were male and reported selling their produce through an auction house, a farmers market, and/or their farm stand. The few USDA Certified Organic participants marketed through Green Field Farms, ${ }^{3}$ a Certified Organic Plain Community farming and marketing cooperative.

Over half the Amish growers focused on goals of "having work for the family" and providing a "good family environment." Believing strongly that "work's good for them," the Amish expressed the importance of these values "to teach children to work and have them all involved." This differs from other similarly scaled farmers in their desire for exclusively on-farm occupations to ensure that household members do not need "to work away [from the farm]." Other motivations included farming "in a way that the children enjoy," and having "enough to sustain expenses and provide a wage for everybody [in the family and community]." Two growers concisely summarized these as their goals for their farm:

To supply an occupation and a living for the family in a sustainable manner so that my children can do it after me.

Our goals are to have the farm be selfsustainable so that it paves the way for the next generation.

Table 2. Participant Demographics and Descriptive Data

\begin{tabular}{lccccrrr}
\hline \multicolumn{2}{c}{ Age of Participants } & $\begin{array}{c}\text { Farm Income } \\
\text { Number of } \\
\text { Age Range }\end{array}$ & $\begin{array}{c}\text { Income Range } \\
\text { (in US\$) }\end{array}$ & $\begin{array}{c}\text { Number of } \\
\text { Participants }\end{array}$ & $\begin{array}{c}\text { Farm Characteristics } \\
\text { Descriptive Statistic }\end{array}$ & $\begin{array}{c}\text { Number of } \\
\text { Workers* }\end{array}$ & \begin{tabular}{c} 
Years Farming \\
\hline $20-29$
\end{tabular} \\
$30-39$ & 3 & $<\$ 50,000$ & 4 & Mean & 60 & 11 & 10 \\
$40-49$ & 5 & $\$ 101,000-\$ 250,000$ & 1 & Minimum & 6 & 9 & 9 \\
$50-59$ & 1 & & & Maximum & 144 & 21 & 18 \\
\hline
\end{tabular}

*This includes workers of all categories: full time, part time, household (adults and up to 14 children).

${ }^{3}$ Green Field Farms is an organic, Plain Community-only cooperative that was started by Amish produce growers in the Holmes County Settlement in 2003 in response to the continued decline of farming as a full-time occupation in Amish communities (Greenfield Farms, n.d.). 
Growers reported that most of the obstacles and challenges to farming and achieving their goals are related to natural occurrences perceived to be largely out of their control. Half of the growers mentioned weather or pests (insects and weeds), and 35 percent mentioned plant diseases. Unlike other produce growers in the study, Amish growers did not mention, without specific prompts, labor, pathogens that cause foodborne illnesses, food safety issues, or the economics of farming as barriers to reaching their goals. Each of these challenges was mentioned by other small-scale produce growers in the study (reported in Parker, Wilson, LeJeune, \& Doohan, 2012b). One grower noted that marketing is not a large concern since they "have the auction." Another grower jokingly replied that the greatest barrier is his role in the "mismanagement of the farm." No one mentioned government regulations, which is surprising given their history of contesting government mandates and their concerns regarding FSMA that emerged later in the interview.

\section{Understanding and Use of Good \\ Agricultural Practices}

Amish growers were asked about their knowledge of the introduction and spread of contamination sources on the farm, if they practiced specific foodborne illness prevention activities and, if they did, whether the prevention activities were based on GAP. The local auction house implemented a voluntary produce safety program called the Growers' Code of Excellence that consists of standards with which all participants in the program must comply. As a benefit for participating, growers are allowed to sell their produce using the Seal of Quality label signaling program compliance to buyers. Two of twelve growers (17 percent in this study) responded that they use GAP.

\section{Perceptions of Source and Prevention of Pathogens} In the interview guide, we differentiated between types of contamination and sources of contamination to distinguish between the specific type of contaminant (e.g., a pathogen such as norovirus) and the source or manner in which contaminants are introduced or spread on the farm (e.g., machinery, people, wildlife). When discussing types of contamination, 75 percent of Amish growers mentioned Salmonella and E. coli, but most growers did not discuss other pathogens such as noroviruses or Shigella. This is likely because of grower familiarity with these first two pathogens as sources of recent food safety contamination outbreaks that have been given higher profile coverage in the media (Webster, Jardine, Cash, \& McMullen, 2010), as many Amish growers reported to us that they use print media as an information source.

We grouped potential sources of contamination into eight categories reflecting dimensions of the four "farm problem areas" identified by Parker et al. (2012a) (Figure 1). These areas include animals (livestock and manure) and wildlife, farm workers, water quality, and facilities and equipment. Chemical contamination and sources of contamination from horses were two additional categories used by participants. Off-farm pets and people were additional categories outside of those mentioned by experts.

The Amish reported prevention goals and implementing practices that often mirrored the types of risks reported (Figure 2). Many of the Amish said their goal was to provide clean produce that does not pose a risk to their customers. Prevention activities targeted specific contamination hazards, such as worker hygiene, produce washing or rinsing (not sanitizing), facility and equipment sanitation, and water quality.

\section{Farm Workers}

Sources. On this topic, many Amish growers expressed unease or difficulty with the concept of referring to their family members as labor, employees, or workers. Fifty percent of growers discussed worker hygiene and habits in terms of personal hygiene practices, such as hand washing, boot cleaning, and produce handling that are necessary for produce safety. A few framed their concerns as an issue of hired workers not receiving proper training or not complying with hygiene requirements. This suggested to us that the hygiene and habits of household and family members are adequately addressed and not perceived to be a problem.

Most participants (67 percent) spoke generally 
Figure 1. Perceptions of On-Farm Sources of Contamination Among Amish Produce Growers

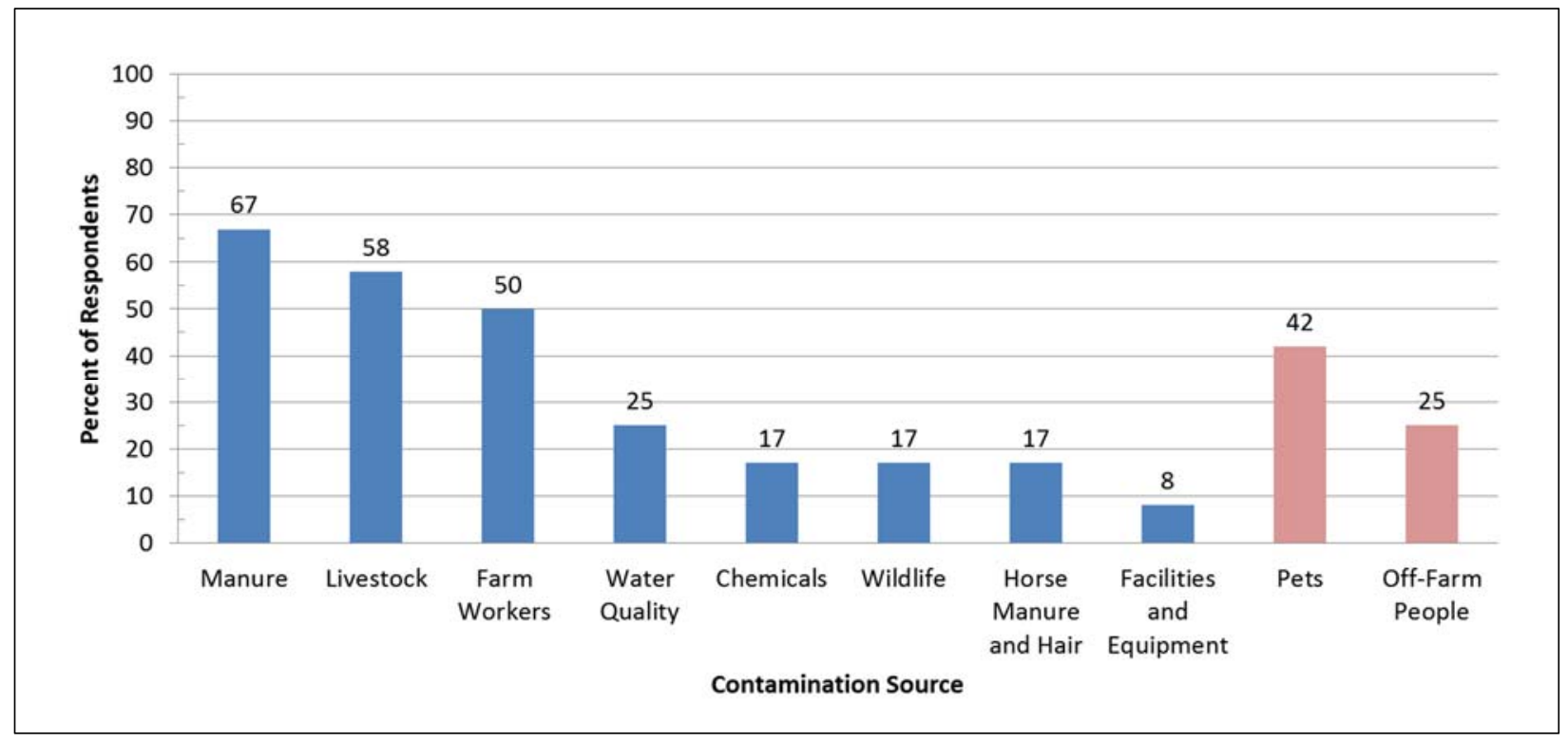

of "people" as contamination sources, sharing their perspectives that personal hygiene includes good hand-washing after bathroom breaks or manure handling, and access to and use of portable toilets and hand-washing stations. For some, this included establishing standard operating procedures (SOPs) for hand-washing between these activities and those involved in produce handling or produce-related field work. It was unclear for some whether the SOPs were implemented in

Figure 2. Perceptions and Beliefs of Prevention Practices Among Amish Produce Growers

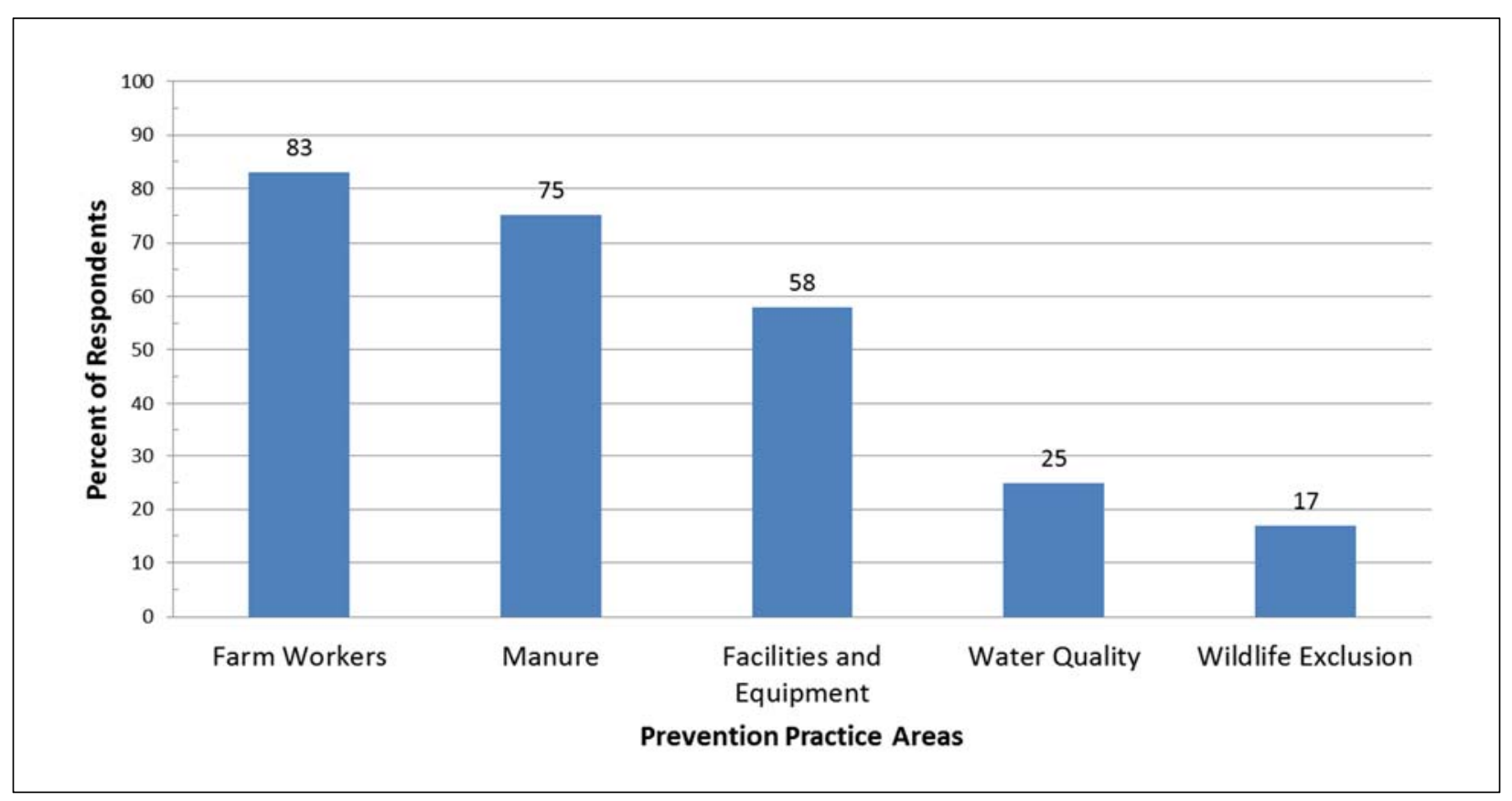

4 "People" refers to employees, but Amish are reluctant to they tend to be family and friends. 
written or oral form. Some growers (33 percent) discussed the importance of keeping their boots clean, washing their boots, or maintaining separate boots for working with animals and manure and when handling the produce.

Prevention. Eighty-three percent of growers said that hand-washing is a key part of preventing contamination from people. One grower said that workers participate in mandatory hygiene training, which occurs at the beginning of every field season.

\section{Animals: Livestock and Manure, Wildlife}

Sources. A majority of growers (67 percent) mentioned manure as a potential source of produce contamination. Livestock was mentioned by most growers (58 percent) who offered multiple concerns regarding livestock in the fields as well as having packing containers in a vehicle that previously held livestock. Alternatively, participants did not think that manure (33 percent) or livestock (42 percent) were potential sources of contamination. A reason for the lack of concern about animals is that the questions were not specific in distinguishing between production animals and work animals such as horses, an important distinction given the perception among many experts that horses are a pathogen source (Lengacher, Kline, Harpster, Williams, \& LeJeune, 2010). Many felt that wildlife does not pose a threat, while the few who acknowledged this source felt there is little prevention that can be done because wildlife are viewed as a part of the natural environment in which food is produced.

Prevention. All Amish growers discussed using manure on their farms. A majority (58 percent) mentioned implementing practices for manure and animal use, but perceptions of best practices varied in the reported days-to-use of composted manure or days-before-planting of other manure:

- Composting manure before use in produce fields was discussed, but specific standards were not mentioned.

- Purchasing bagged, composted manure to avoid using raw or improperly composted manures. However, production standards for ensuring adequate pathogen kill were assumed and not confirmed.

- There are standards for farmers to follow for timing of manure application during pre-planting and pre-harvesting intervals, but there was confusion among some as to what these are, including the Seal of Quality rule:

- Timing of pre-planting manure spreading: the application of manure to fields before planting seeds by following a protocol ranging from 90 to 120 days, with some up to one year prior. Some did not use raw manure in spring as a preventative measure and emphasized spreading composted manure a minimum of 90 days before planting.

$\circ$ Timing of pre-harvest manure spreading: the application of manure to fields before harvesting a crop by following a protocol of 120 days before harvest. One reported adhering to a 90-day schedule.

- Using separate equipment in produce fields and for use with animals, manure, "barn work," and other row crops such as corn and oats.

- While growers reported inspecting and cleaning equipment, none reported using a standard operating procedure for this. Equipment cleaning regimens are needed to establish a system to visually inspect and clean potentially contaminated equipment before use with produce.

- Changing or cleaning boots when moving between produce and areas where contamination may occur.

Focus Areas. Many who perceived produce growing and wildlife as existing in the same natural system felt that prevention of wildlife from entering their fields was unrealistic and did not believe they had the ability or resources to prevent this from being a problem. Those who said they make no extra effort to prevent wildlife from contaminating produce recognized that animal droppings should be removed from the field and they should not sell 
any produce that came in contact with feces. There may be a need to provide guidelines for how to inspect and to clean equipment. The smaller scale of fields and implements may make the maintenance of separate equipment an acceptable alternative to cleaning, but information on the time and economic dimensions of cleaning versus maintaining separate equipment would be useful further research.

\section{Irrigation and Wash Water}

Sources. A quarter of growers (25 percent) mentioned crop irrigation and packing-shed wash water as contamination sources. Most growers (83 percent) mentioned concerns from surface waters such as ponds and creeks that are used for irrigation, with drip irrigation being the most common form mentioned. Half of growers (50 percent) discussed using well water primarily for washing produce and just a few (17 percent) discussed using it for irrigation. Some felt that deep wells that are sources of wash water do not need to be chlorinated regularly, but chlorinated either annually or biannually.

Prevention. Water quality was perceived as an issue by some growers who use bleach or other chlorine-based products in manual washers or with solar- or windmill-powered pumps. Soaps to wash equipment, like VEX, were also mentioned. Testing water for $\mathrm{pH}$ level and pathogens, such as coliforms, was mentioned by 25 percent of growers. Additionally, some growers reported using drip irrigation systems or installing livestock exclusion fencing or wildlife barriers around ponds and other surface waters used as water sources. Other practices included flushing wash-water supply lines prior to washing produce and irrigating under plastic to prevent water from contacting edible portions of produce. Despite the widespread recognition of the importance of these prevention practices, some growers said they do nothing to assure adequate water quality used for irrigation or washing.

Focus Areas. The study participants had questions about the risks of pathogen contamination from various combinations of water sources and irrigation methods in addition to water testing. Some said that irrigation or wash water is a potential source of contamination, but few, including those who do test, had concerns about their own sources.

Additionally, some stated they do not test for pathogens or use any contamination prevention practices. Some farmers perceived deep-well water sources as safe and believed they do not need to test for waterborne pathogens. While Amish assigned greater risk to surface water sources, few mentioned the need for testing this water source. There was no association between those who reported testing their water sources and those stating they practice chlorination of their well water.

\section{Chemical Contamination}

A few growers (17 percent) discussed concerns related to foliar applications of herbicides and other pesticides that would leave residues on the plants and potentially contaminate irrigation or produce wash water (Figure 3). "Chemical contamination on vegetables" from applications and "from roadside spraying" were specific sources of contamination risk introduced from off-farm. These perceptions were shared from other smallerscale produce growers in the study and differ with growers on larger farms (Parker et al., 2012b), and from those emphasized by experts. There was concern among these growers that produce safety standards would not address this issue.

\section{Facilities and Equipment}

Sources. When asked specifically about their equipment, half of growers (50 percent) said it could be a source of contamination when used in the fields and packing sheds. The rest felt there is little risk because they wash their equipment before using it with produce. One grower stated that he uses "dedicated equipment" for produce. Amish growers differed from other groups of produce growers (i.e., small, medium, and large; see Parker et al., 2012b) in their concern for pets and horses (50 percent for each category). This latter concern was expressed with an emphasis on expert assumptions that horse manure is a source of E. coli, which is a contested position among the Amish. Growers focused their concern on draft horses being in the 
Figure 3. Greatest Concerns for On-Farm Sources of Contamination Among Amish Produce Growers

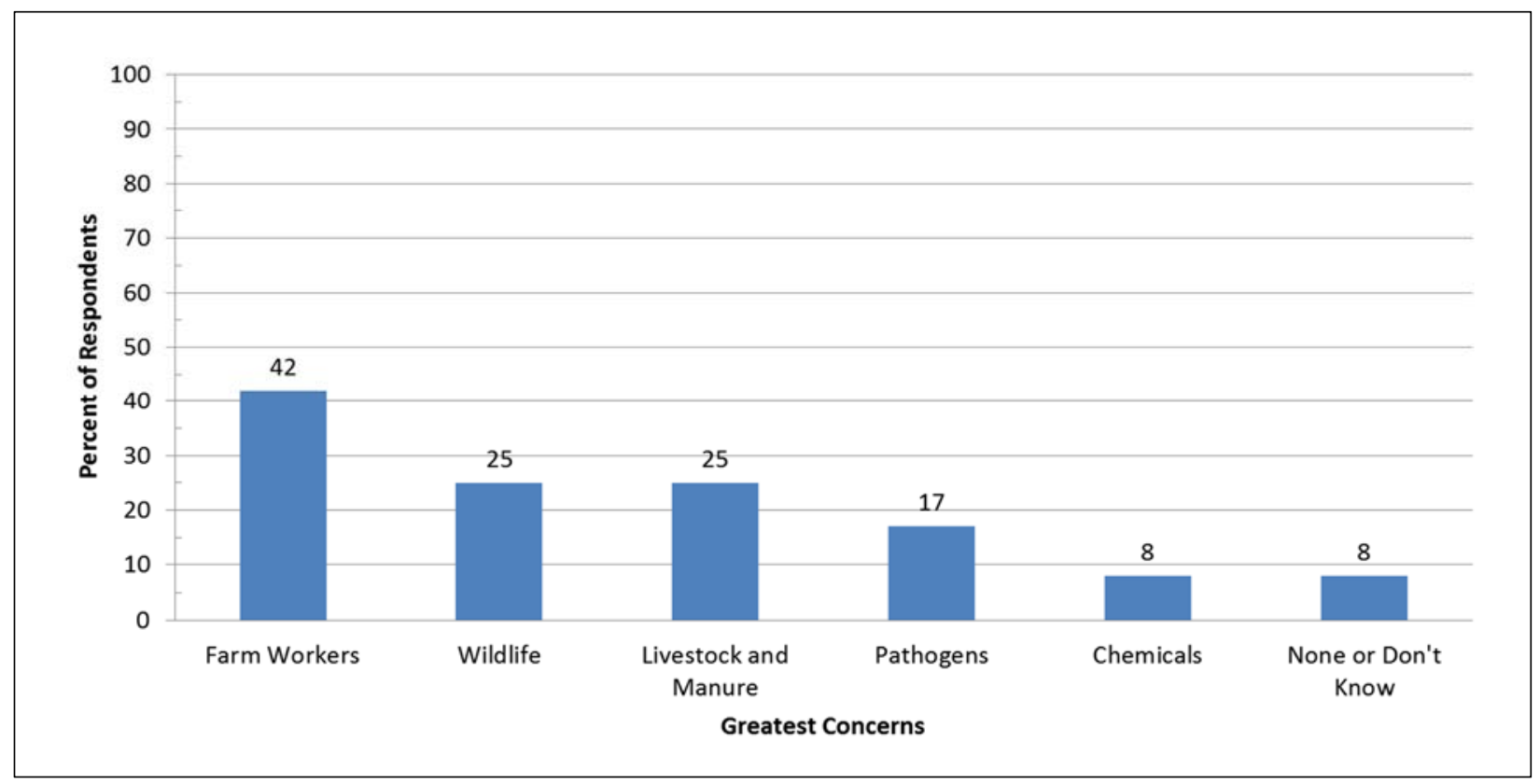

fields where they could defecate near produce or surface waters used for irrigation or packing shed water. Many spoke of minimizing this risk of pathogen transfer by ensuring that the people driving horses are not harvesting produce and providing paths in their fields for horses to walk and avoid contact with produce.

Prevention. Equipment sanitation was mentioned by most growers in the context of other practices, such as washing equipment (58 percent) and keeping equipment that is around manure separate from produce equipment (33 percent). A few said they make no extra efforts to prevent equipment contamination. Examples of equipment sanitation focused on carts and implements, while harvest bin or basket sanitation and stacking practices were not mentioned.

\section{Other Sources of Contamination}

Forth-two percent of the Amish growers identified pets as potential sources of pathogens. This includes pets residing on the farm as well as those that accompany visitors to farms, auction houses, and farmers' markets. Horses, specifically their manure and hair, were viewed by a few (17 percent) as potential sources of contamination, though there was doubt because of the long history of horse use on farms. People not associated with the farm were viewed (by 25 percent of respondents) as sources that could not be controlled. Visitors, customers, and their children were included in this group.

\section{Greatest Concerns}

Regarding the greatest areas of concern for potential produce contamination on their farms, many Amish growers mentioned overlooking handwashing (42 percent), poor manure management (25 percent), and wildlife in the fields ( 25 percent) (Figure 3), which was similar to other small-scale growers in this study. Within the content area of livestock and manure, growers felt that "crosscontamination from the horses to the packing house" is the greatest concern. This is not because they see horses as a genuine risk, but due to their concern for regulations prohibiting the use of horses on produce farms; they contested the risks posed by horses by insisting that horses are less likely than calves or dairy cows to spread contamination, a position supported by recent research (Lengacher et al., 2010) and GAP produce recommendations (Barinas et al., 2010). The anxiety of potentially losing horses from their produce 
operations overshadow their concerns for other risks. While this concern is contradictory to their stated belief that government regulations posed few barriers, participants' responses were consistent with the testimony of Amish produce growers at the USDA National Leafy Green Marketing Agreement hearings (USDA, 2009) regarding the ability of the proposed standards to damage their operations.

The proximity of "baby calves" to the barn and/or pack shed was named as the greatest concern. This may be a common concern because of the repurposing of animal facilities for produce washing and packing on many evolving farmsteads. In addition, risk from the quality of the water used by "the guy that sprays the roads" to control dust from cars and buggies highlights a perception among many growers, Amish and others alike, that risks outside the farm are not addressed in developing produce safety regulations. This intersects with perceptions that many sources of pathogens or contamination are beyond the control of most growers. A focus on the unknown or uncertainty in risk assessment is common among non-experts (Hansen, Holm, Frewer, Robinson, \& Sandøe, 2003; Webster, Jardine, Cash, \& McMullen, 2010), as it highlights the existence of uncertainty and contests the focus on the practices of the group in question (i.e., Amish or other smaller-scale farming practices). Alternatively, farmers tend to minimize risks involved in routine or familiar activities (Salamon, Farnsworth, \& Rendziak, 1998).

\section{Goals for Preventing Contamination}

Most growers (67 percent) responded that worker hygiene and facility and/or equipment sanitation are high priority areas to prevent contamination. As noted by one grower, "Clean packing house, clean workers and hands, clean equipment, sanitized boxes" are the goals. A majority (58 percent) noted a goal of providing produce that poses no risk to their consumers. Additionally, some stated that their goal is to help consumers, believing that:

Our public, the end consumer, is living in a pasteurized world and they have no natural pathogens to ward off Salmonella and E. coli.
A minor goal of some growers (25 percent) is to "stay within limits of spreading manure [between] 90 to 120 days before planting." While many Amish growers are aware that there are guidelines for manure composting and raw manure use, there is a degree of misperception regarding the timing of manure application with regard to pre-planting versus pre-harvest intervals. There may be a need to provide clear guidelines on the timing and rate of application.

Most growers recognized that their buyers have the greatest influence on their prevention goals because buyers "don't have authority, but they influence how we do things" by deciding to buy from them. Government regulations have very little influence, as noted by one grower who said, "Not an issue. Not sure they have regulations." At the time of this research, many growers preferred to avoid government regulation and felt the Amish could do this if the auction house were to be proactive about food safety. The Seal of Quality program at the auction house is seen as an example of a proactive approach. This program was mentioned by some growers as a way of "making our own regulations to keep the government out of it."

\section{Barrier to Prevention}

A majority of the growers interviewed (58 percent) said that they do not perceive any barriers to adopting prevention practices on their farms (Figure 4). When prompted, however, a third of Amish produce growers (33 percent) perceived new technology as a barrier to broader implementation of some GAP because "we don't have access to modern technology." This is not just because of religious reasons but because the technology is not perceived to be locally available "unless [it is] brought in." One farmer each said that many practices, without giving specifics, "slows up harvesting," while another believed that their dependence on "horses are the biggest barrier to fully complying with GAP."

The two-thirds of growers who perceived no barriers to technology or specialized equipment felt that they could gain access to it if needed. This misperception of access is problematic because most preventative measures need to be in place to avoid an incident; there is little time to implement 
Figure 4. Perceptions and Beliefs of Barriers to Adopting Prevention Practices

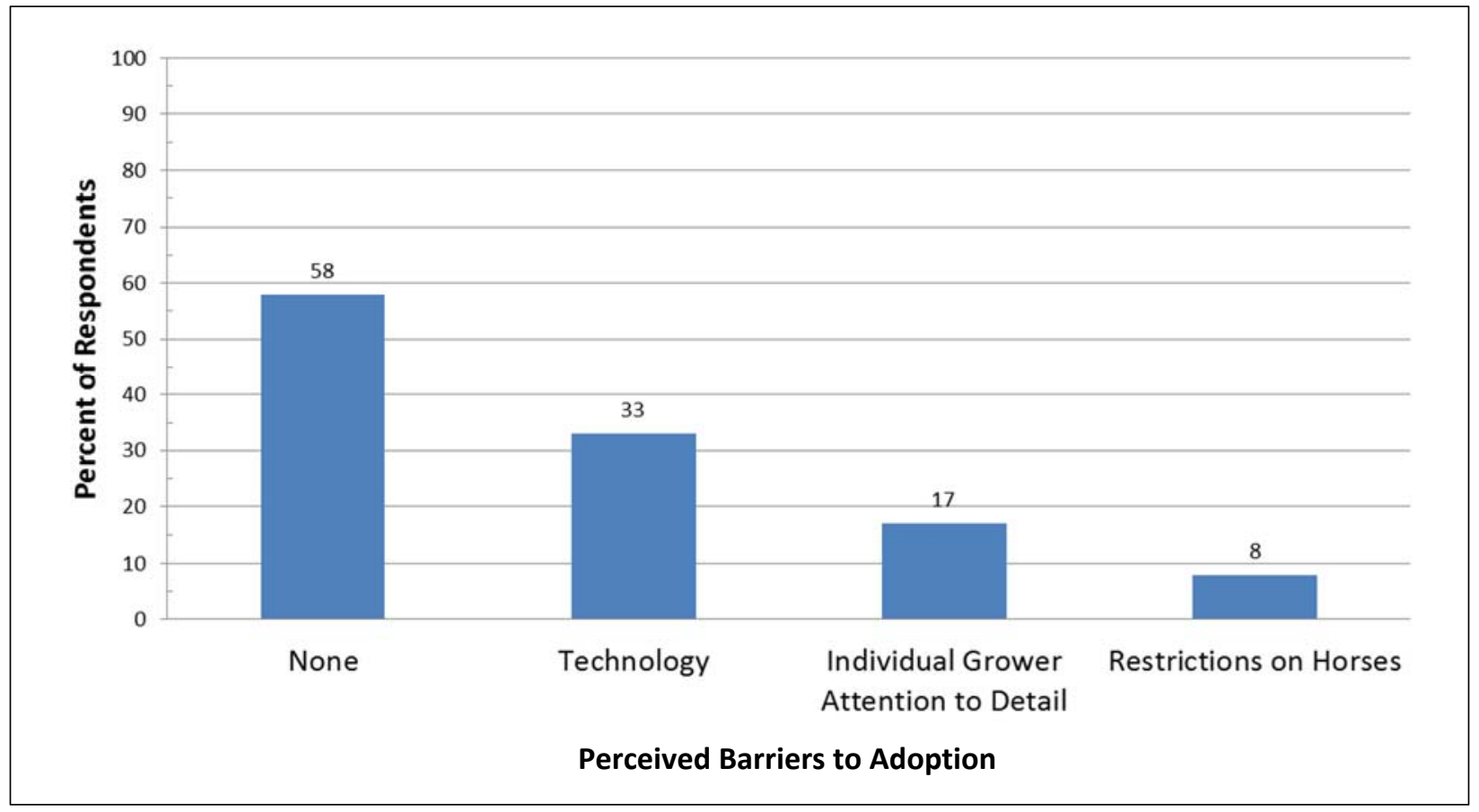

prevention practices when an outbreak is already in progress. The perception that many produce safety technologies are inappropriate for the Amish (one grower noted that "most everything is electric") is potentially both a real and a perceived barrier that will need to be addressed. There is a belief in this community that if federal-level food safety rules are created, then standards would be created, causing all produce growers to adopt the same or similar practices of large-scale operations. Further, there is concern that federal-level standards would necessitate technology-intensive practices because they would be led by larger-scale interests.

Information was specifically requested on $E$. coli and other contamination risks and best practices for using draft animals for moving produce through and out of the fields. Growers requested that information and best practices be adjusted for farmers operating at scales as small as 1 to 10 acres ( 0.4 to 4 hectares). They also need training with appropriate technology and delivery methods that contain scale- and risk-appropriate recommendations on prevention, traceability, and food safety practice documentation for small farm operators selling to the auction house or directly to consumers. This may include the use of stickers with producer "lot numbers" that include the field on that farm number and date of sale.

Amish growers mostly felt that the approach used by the auction house was appropriate, which gives it the potential to be adapted to other settlements, Plain communities, and other smallholder farmers.

\section{Preparedness for On-farm Contamination}

Growers discussed their level of preparation for dealing with an on-farm contamination incident (Figure 5). A few growers (17 percent) stated that they were "very prepared" because they had attended grower meetings on the topic and participate in a recall program through the auction house. Yet, most believed their teams were only "somewhat prepared" and talked about actively developing food-safety procedures for their farm but were "slow in getting it where it should be." Others felt that their lack of practical experience for dealing with an event was a barrier to being fully prepared, which is aligned with the common belief that experience in an activity is a good predictor of performance. 
Figure 5. Self-reported Level of Preparedness for Dealing with an On-Farm Outbreak

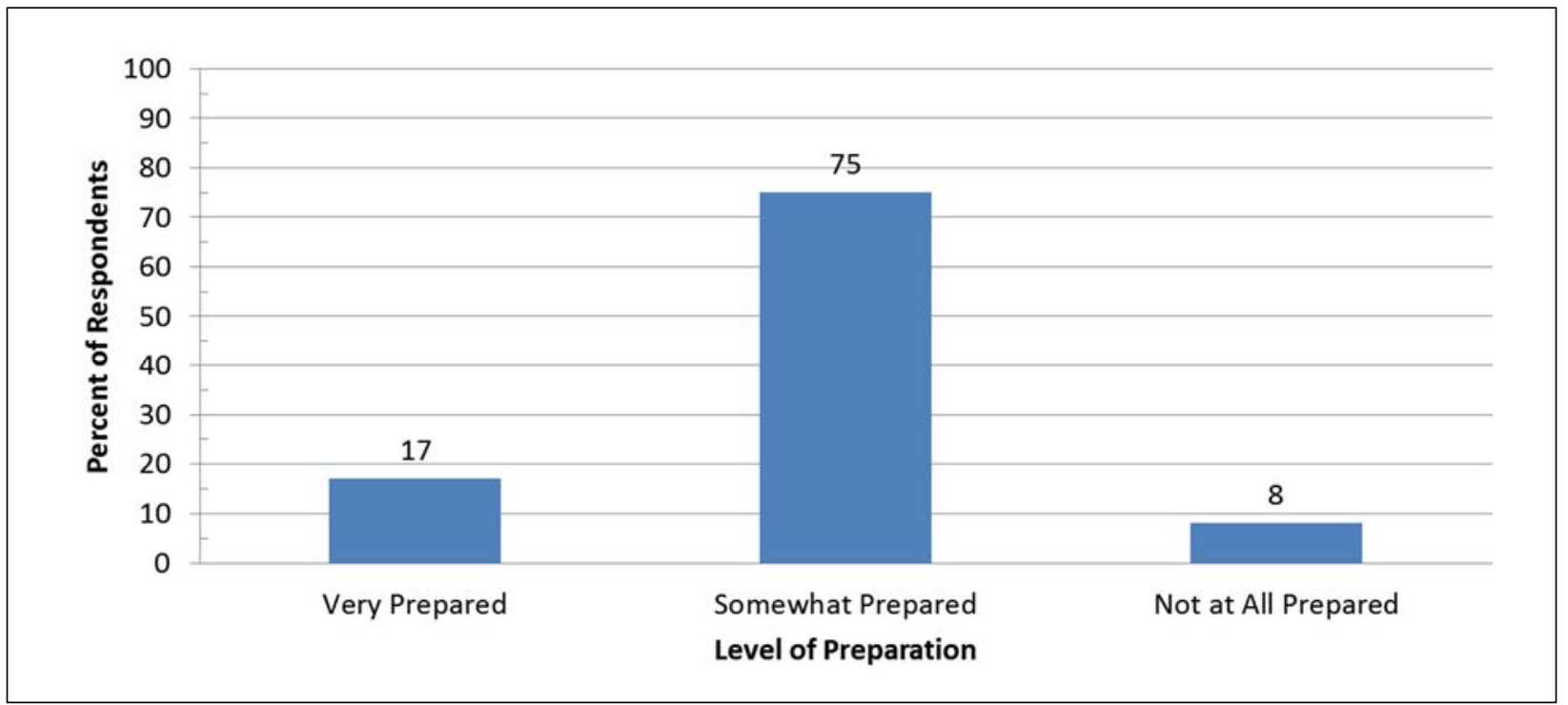

Most growers mentioned the produce auction house as the main influence on prevention practices they follow. As one grower indicated when asked if he practices GAP, "We don't strictly follow [GAP], but 'yes' based on [practice recommendations] supplied by produce Auction meetings." Responding to questions of how farmers would know there was an outbreak on their farm, half of growers (50 percent) said that a customer illness being traced to their farm would be the most likely way of learning there was a problem, while some (33 percent) believed the produce auction could trace contamination back to their farm using the lot stickers assigned to each unit of produce. One grower mentioned that he was able to visually identify the contamination on the produce. Most growers (67 percent) said they would respond to the contamination by testing, recalling, and destroying the crop and doing "everything needed" to address the issue. These perceptions prompt the question of whether farmers are prepared to adequately handle a contamination event when most report being only "Somewhat Prepared," have vague ideas of what GAP certification is, and at least one believed that a visual inspection could reveal such an event.

Impact to their Farm and Markets. Nearly all (83 percent) growers agreed that an incident on their farm would affect the ability to market the same or similar produce or could even "put them out of business." A small minority felt that personal relationships with their customers would buffer them from serious losses. One grower believed that an outbreak may not affect them because produce is not their main source of income, or "their bread and butter." Many (58 percent) growers felt that even an incident on another farm producing the same crop as theirs would have negative effects for them.

\section{Information Sources and Needs}

Growers identified three types of information sources on produce production for which they had unique preferences: general produce growing information, produce safety prevention practice information, and produce safety information for dealing with a produce safety breach. Growers reported that most of their general farming information comes from within their community (Figure 6). While growers could choose more than one source, just one grower (8 percent) said that "University Extension" would be a source of general farmrelated information, while most (67 percent) responded that family, friends, and neighbors were their likeliest source and half (50 percent) reported relying on the auction house. A few growers noted the role Extension has for supporting the auction house as an information provider. While Extension 
Figure 6. Preferred Channels Among Produce Growers for General Farming Information

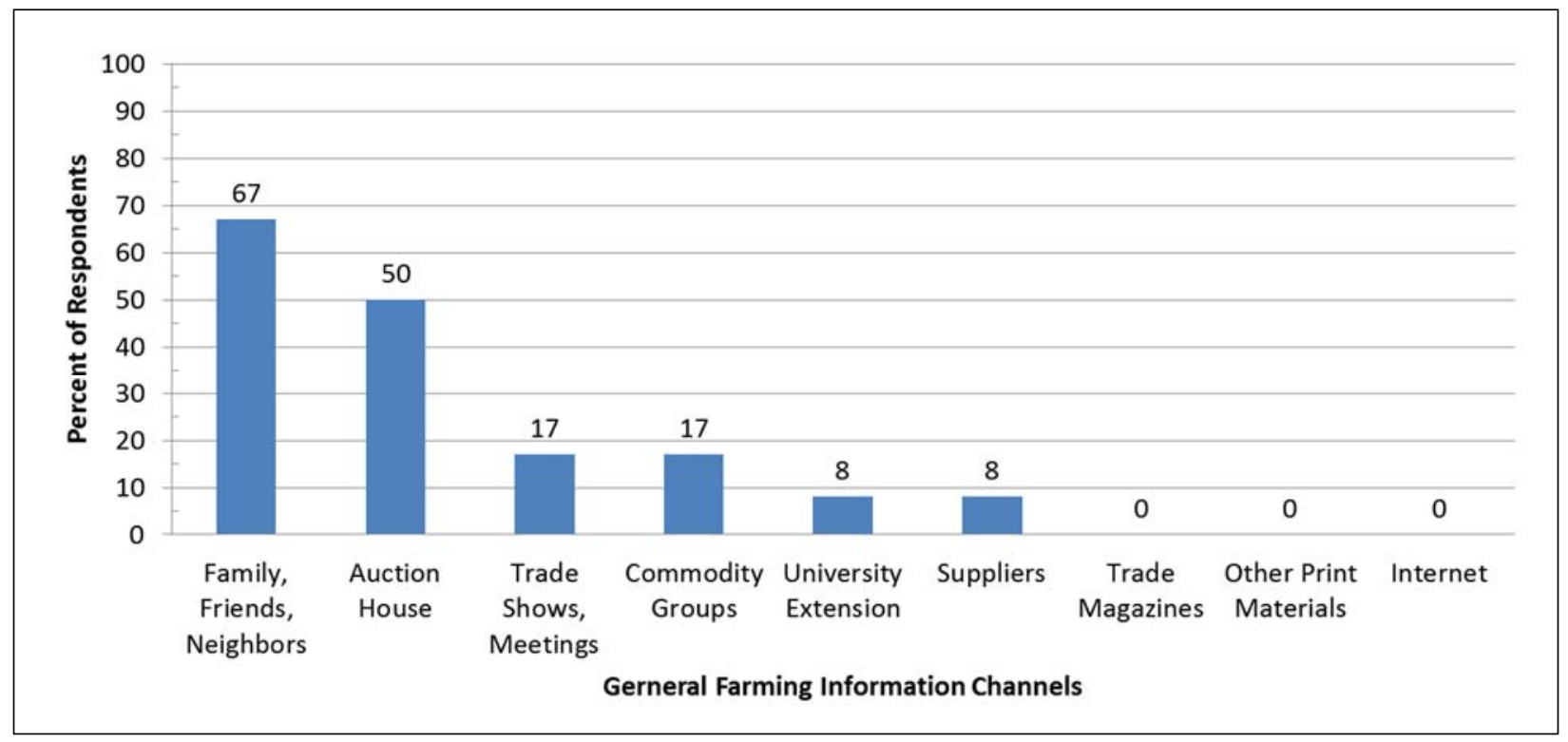

rated low as a general information source, several growers mentioned specific Extension agents with whom they work and who would be their first contact. This preference highlights the importance of interpersonal relationships and the value of an individual's expertise and experiences rather than the institutional presence.

When discussing specific produce safety information sources (Figure 7), a majority (58 percent) said they would go to "University Extension." Some added that Extension agents have the most useful resources on the topic because of their scientific knowledge and most of them had a willingness to help. Commodity groups that work closely with growers, such as produce grower associations and dairy advocates, certifying

Figure 7. Preferred Information Channels for Sourcing Produce Safety and Contamination Prevention Information Among Amish Produce Growers

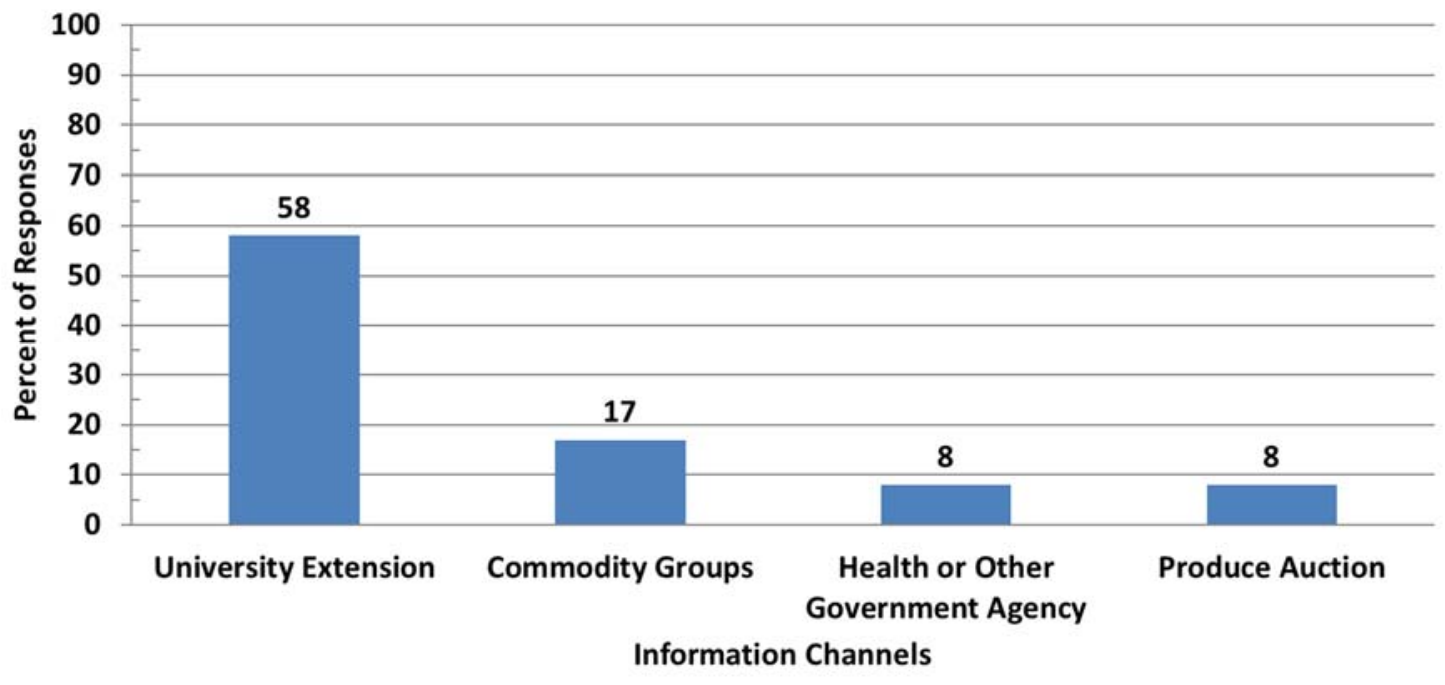


Figure 8. Preferred Information Channels for Dealing with an On-Farm Outbreak

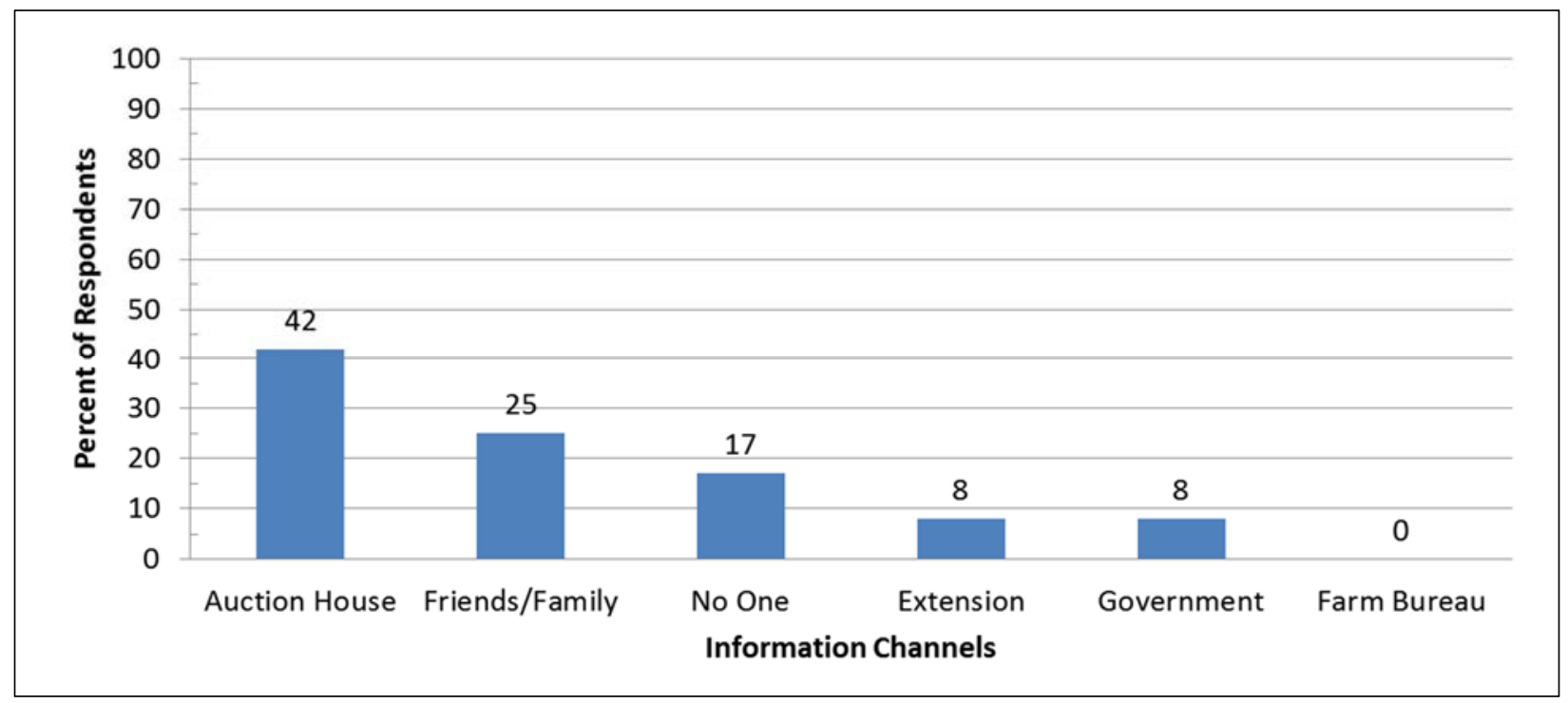

groups that facilitate NOP certification, and other growers were also mentioned by a few as potential resources. Growers rated the auction houses the same as they did "Health or Other Government Agency." We believe this low rating is due to growers knowing that much of the auction house information is likely to be sourced from Extension.

In seeking information specific to a contamination event, the auction house was the most cited source of support, with many (42 percent) saying they would contact them for help. No growers offered unprompted examples of seeking outside help beyond the auction house (Figure 8). When prompted, a few (8 percent) indicated that they would consult with "University Extension," consultants, salespeople or other sources for assistance. Government sources, particularly the health department, received little consideration (8 percent). Several growers ( 25 percent) would rely on friends, family, and other growers to help them deal with such an event, and some from this group mentioned specific local growers who were also agricultural suppliers in their community. Participants identified produce safety risks from horse traction in plowing and for transporting produce around fields and to markets as a paramount information need. The seemingly inconsistent response regarding the role of the auction house as information provider is the likely result of trust and high regard for the channel of information (e.g., a local community group) over the source (e.g., a sciencebased Extension publication). The trust placed in a local in-community information channel may be more important than the potential quality of that information, because local channels are perceived to have a lower risk of government involvement, which could reduce the risk of the outbreak threatening their livelihood. Quality and reliability of the information was of particular importance for sourcing farm-related and food safety information, but actually dealing with an outbreak incident was layered with the criterion of discretion.

When prompted about effectiveness in dealing with a produce-related foodborne illnesses, growers were asked to rate institutions as either "very effective," "somewhat effective," or "not effective" for helping to deal with an incident. Fifty percent of growers said Extension would be "very effective" and 25 percent "somewhat effective" in responding (Figure 9). Government agencies were viewed as less responsive with lower ratings of "very effective" (17 percent) and "somewhat effective" (25 percent) as growers felt that their operations were either too small for the government to care about, or that they simply "don't trust them." The ratings of commodity groups (e.g., the Farm Bureau) were relatively low for "very effective" (17 percent) and "somewhat 
Figure 9. Perceptions of Institutional Effectiveness in Assisting in an Outbreak

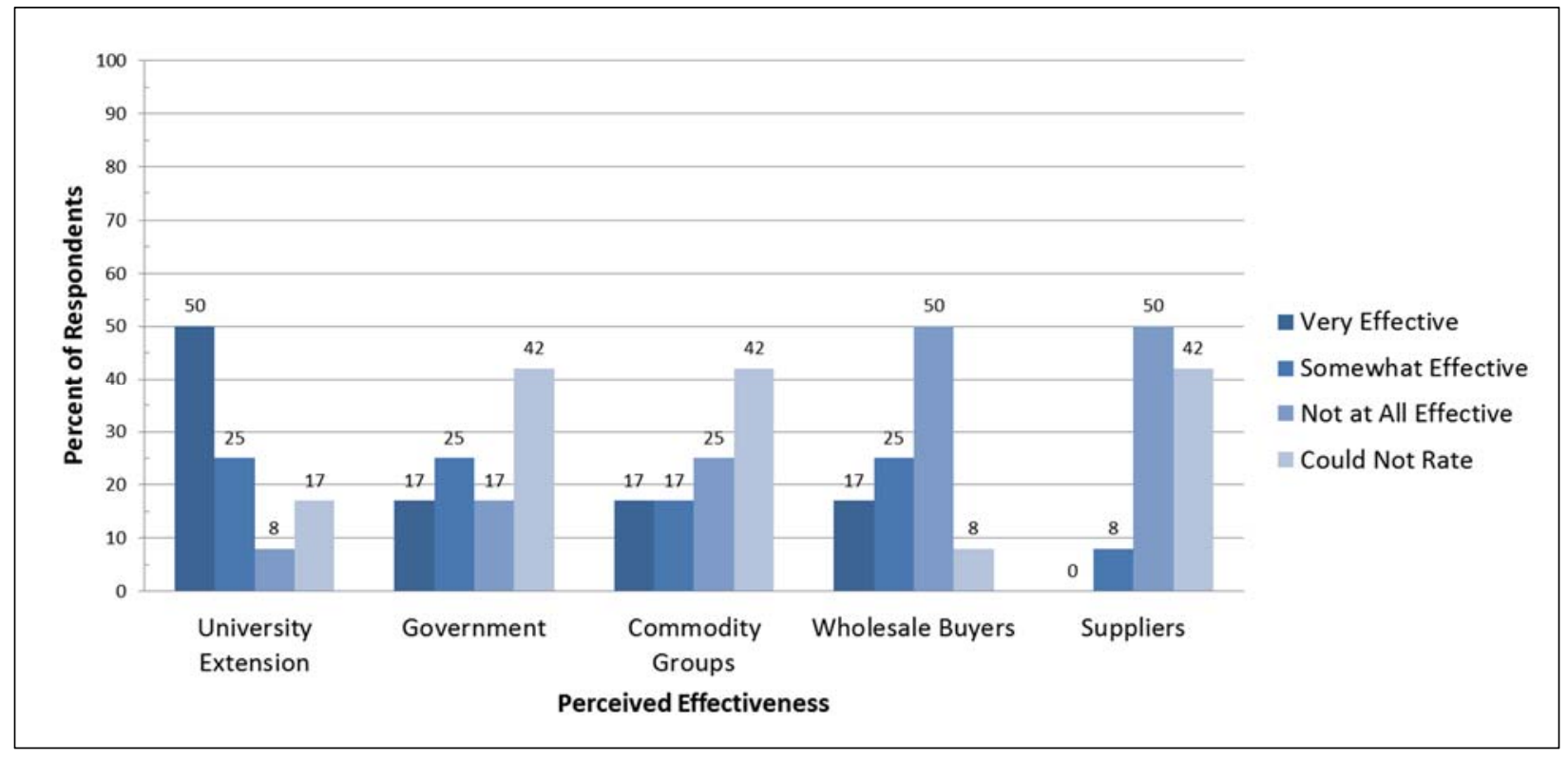

effective" (17 percent), and a quarter responded that they were "not effective" (25 percent). Half of growers responded that both suppliers and wholesale buyers were "not effective" (50 percent). Wholesale buyer effectiveness was questioned because some felt their buyer, the auction house, was just a "middle man." A few believed that wholesale buyers would be "very effective" (17 percent) or "somewhat effective" (25 percent) because "they would stop me from selling my produce" which would control the outbreak. Most growers choosing not to rate, or could not rate, did so because they were unable to identify the role of the group for acting in this situation.

Many growers conflated the purpose or goals of the GAP standards, the Seal of Quality requirements, and the use of auction house lot stickers. Some perceived that the lot stickers, for instance, were part of the Seal of Quality and thus were a part of the GAP training that the auction house offered and could be used for tracing a contamination event to a farm. While this was a proposed additional use of the lot sticker, its purpose at the time of research was to identify the owner of the produce for sales records.

Despite many acknowledging that they were not fully prepared, 67 percent said they did not need more information, which may be the result of a barrier some Amish growers erect to avoid repeated contact with people outside their society and a preference for handling problems internally. A few inquired about the potential for field contamination resulting from using drip irrigation. A few (17 percent) were concerned about pathogens being absorbed into the plant through the root system and being transported through the vascular system to edible parts of the plant. Others said they needed more information sources on the spread of E. coli contamination. One grower was unsure about the tools or practices available to prevent wildlife contamination in their field, but stressed that their concern was about wildlife eating their crops. This expanded perspective could be used to combine grower interests with a need for addressing this risk.

Preferences for information-seeking match our expectations from past interactions with members of Ohio Amish communities. Most growers (83 percent) preferred to receive information related to produce safety through the mail. A few (33 percent) responded that trainings and other in-person visits were preferred. (Growers could choose more than one source.)

One-quarter (25 percent) of growers said they participate in food safety programs conducted by the auction house, half (50 percent) said they plan 
to participate in the future, while the remaining quarter said they did not plan to participate. One grower said that he did so only because the auction house required it, a misperception given the voluntary nature of the Seal of Quality program. Many felt that the auction house already provided the information and trainings they needed to prevent or control an outbreak, despite responses noting that most were not participating.

\section{Discussion}

Produce safety is an issue that can greatly affect a wide range of farmers as a result of the feedback loop created through media coverage, consumer responses, and the evolving regulatory environment. As seen during the 2006 spinach outbreak, produce safety breaches can turn into nationwide incidents that harm or kill many people. In addition, as a result of the lack of transparency in most produce-commodity chains, industry-wide financial losses can occur as consumers use what information is available to them to alter buying patterns and reduce their own risks. The emphasis in this study was to better understand the perceptions, beliefs, and produce safety and GAP certification information needs of the Holmes County Amish. Additionally, many of these recommendations and lessons would be useful for engaging other smallscale, nonmechanized farmers outside the Plain Community. Similarities exist across underserved smallholder farmers (Netting, 1993) for land, labor, capital, and information needs. Many of the perceptions and uncertainties the Amish reported are likely to be held in common by other farmers with similar operation characteristics and marketing practices.

In addition to public health concerns, the effect of a produce contamination incident on Amish communities is potentially great since they are increasingly adopting produce as a viable economic alternative to dairy. The increasing scale and magnitude of produce safety risks, from both threats of contamination and threats of overregulation (real and perceived), has increased the necessity for GAP training and compliance among all produce growers. For the Amish, this raises the importance of integrating produce safety practices informed by accurate information into current farming practices. What follows is a discussion of issues and recommendations for moving toward this goal.

Despite the promise of fresh produce production offering an alternative farming strategy for the Amish, the conflict among their values of separation, the need for consumer protection, and government regulations pose challenges. Like many farmers, Amish growers are unenthusiastic about government-mandated produce safety rules and have past experiences successfully resisting external directives. Few in this study reported seeking GAP training, discussed GAP compliance, or identified a need for more information, which, according to informal sources, is representative of this community of growers.

Much of this guarded approach among farmers is heightened among Amish growers who have a cultural preference, and possess social mechanisms for, in-group problem solving. This preference for handling problems internally is problematic from the position of implementing effective outreach with accurate produce safety information. This research indicates that collaboration with intermediaries, or cultural-brokers, such as auction house staff, could be a path to increasing GAP awareness. A strength of the auction houses are the social networks that intersect in this community space where more liberal Amish and Mennonite farmers historically share deep social and cultural connections across Orders. Moreover, our findings can serve as a benchmark for the range of perceptions and beliefs on produce safety in the Holmes County Settlement, with more general application for other Plain Communities.

\section{Perceptions of Produce Safety}

Holmes County Settlement produce growers have unique concerns. Many of the participants reported varying awareness of pathogens, sources of contamination, and practices to prevent or control them. Despite some awareness, most do not feel adequately prepared to handle an on-farm outbreak, and they perceived barriers to adopting some of the prevention practices. A self-reported lack of preparation and in-group problem-solving preferences can compound the issue of providing salient outreach, as described below. Few felt that 
there were risks in their type of farming as long as they follow the practices prescribed by the auction house.

\section{Amish Cultural Model of Responsibility}

Findings reveal that the Amish both highlight and contest the high level of responsibility they feel is placed on farmers for ensuring produce safety. Many of their perceptions highlighted consumers as potential sources of their own contamination and risk. Connected to the perception of consumer responsibility is the belief that consumers share blame for their perceived susceptibility to illness by reducing their exposure to general pathogens that results in having underdeveloped immune systems. The logic of this is as follows: Amish perceptions of E. coli and Salmonella were related to the recent discourses on national foodborne-illness incidents, and perceptions of these incidents were shaped by the belief that people in non-farming communities have a weakened immunity to natural pathogens. Several believed that consumers have been removed from the production end of the food system and no longer experience daily or routine exposure to the natural environment and its pathogens. Further, they perceive that pasteurized foods, antibacterial hand sanitizers, and other antimicrobial household products work in the shortterm to protect consumer health while ensuring that their immune systems remain unchallenged and unable to protect against illness. Further, many would like to see increased consumer outreach to promote greater awareness and improved produce safety practices, holding that most people do not properly clean their produce or food preparation areas before preparing or consuming food, and are responsible for some cases of foodborne illnesses.

Growers contest expert perceptions of horses acting as pathogen vectors. Some growers requested information that included proven findings on equine transmission of E. coli and other pathogens to produce fields. This is in addition to a reported need for increased research on general risks of horse use on Amish farms. Much of the contestation of horses-as-vectors arises in a charged environment that has farmers of different scales of operation, and consumers, looking for solutions to complex issues spanning the food system; these issues are often beyond the scope of current experience and knowledge of most people.

Growers shared perceptions that emphasize control rather than prevention of produce contamination. They viewed prevention practices as activities they could implement to control the introduction and spread, but not as practices that would prevent such incidents. This emphasis on control for an already present risk is shared across farm scales (Parker et al., 2012b). Like other produce growers in the larger study, many Amish growers asserted that produce is grown outdoors and they are unable to control all sources of contamination. Consequently, many growers believed that there is little control over the degree to which wildlife affects produce safety because it grows in a natural environment.

\section{Social Networks, Cultural Brokers, and} Best Practices in Adult Learning Cultural sensitivity is important when developing effective outreach for any community. This requires outreach professionals to ensure that the characteristics of their messengers (e.g., verbal presentation style, appearance) are acceptable to audience members, and that messages are crafted and education events are designed with audiencespecific educational needs and culturally appropriate practices in mind (Brown, 1981; Wejnert, 2002). It is best that growers communicate with experts who can provide scientifically based information and protocols for both contamination prevention and outbreak control. The Amish pattern of seeking information from different sources based on information needs effectively separates information for preventing an outbreak from information for controlling an outbreak. This creates a difficult situation for outreach professionals wishing to provide state-of-the-art resources on best practices if they are not a primary channel or source. The risks of negative outcomes are likely to increase if growers are sourcing prevention or control information from non-authoritative sources.

Bell and McAllister's (2012) best practices for adult learning can help integrate current knowledge and prior experiences of growers with new materi- 
als to effectively disseminate information that connects with internal motivations for learning. Moreover, pairing the material with learning styles is important for this process. From our study and outreach experiences, many Amish value practical experience, experiential learning, and testimony from people with these experiences. Applying these principles for Amish audiences can take the form of field days and experiential workshops such as facility, equipment, and/or produce sanitation, anecdotal accounts from people with shared Amish or Plain Community backgrounds, and the use of culturally appropriate and non-electronic learning materials such as posters, workbooks, newsletters, and factsheets.

Social networks of family and other Amish growers are used daily and have significant influences on farming operations. These networks can be approached when developing outreach programs, particularly those designed to influence behavioral changes. A recent national study of environmental perceptions and beliefs (Macias \& Williams, 2015) demonstrates the importance of integrating exogenous social networks in shaping perceptions of environmental issues. Macias and Williams found that people socializing more outside their family social networks tended to report using more environmentally favorable practices than those who socialized mainly within their family networks. These findings highlight the importance of fostering broader, community-level values and the effects on individuals of sharing information and material resources within this larger network.

The strength of existing social relationships between Plain Community farmers and their neighbors is likely to vary across settlements. For instance, one Plain Community may have a longstanding professional relationship with outside local service providers (e.g., the Soil and Water Conservation District) while another may have relatively little contact with people outside its community. Consequently, outreach professionals should be mindful of local trust and comfort levels with information and technical service providers. Building such trust and comfort may require working through different social networks. Relying on gatekeepers in these networks for guidance or assistance can help build program trust among Amish growers. Outreach professionals wanting to work in Amish communities can use the strengths of existing social networks to enhance collaborations and outreach. Such an approach was identified by Parker et al. (2006), where relationships within and across Amish Church Districts in the Holmes County Settlement were considered when addressing water quality remediation efforts in the Sugar Creek watershed.

Both a source of confusion and a potential instrument for change, the Seal of Quality is a program available for growers to identify their produce as higher quality at the market. Most study participants were aware of the program but did not participate in it, and nearly half of the Amish in this research have misinterpreted the Seal of Quality requirements as covering only pesticide application training and recordkeeping.

The Growers' Code of Excellence and Seal of Quality offer examples of nongovernmental solutions that can expand GAP compliance by shifting program participation from a voluntary to a universally mandatory participant signup. In collaboration with Cooperative Extension or other outreach providers, the auction house is a cultural broker that could require and provide additional guidance and GAP training to all its vendors.

Auction houses offer an entry point to social networks where the power dynamic between buyer and seller is less uneven, and members of local social networks interact internally and externally. Rather than focusing efforts exclusively on the Church District, we recommend working with trusted community members who potentially have different perceptions and beliefs of risks, of control and prevention, and appropriate means of ensuring produce safety. This nonfamilial yet nongovernmental approach pools the authority of local Church District decision-makers with the expertise of produce safety experts who can provide information externally through in-network people, such as auction house staff. To accomplish this, organizers will need input from farmers, GAP trainers, and auction house staff to develop a framework that is more nuanced than these recommendations and include marketing and organizational structures appropriate to each community. 
Partnering with buyers and Amish growers to develop programs that go beyond the voluntary versus coercion dichotomy, and instead includes community leaders and farmers to develop local solutions, is the key. The Seal of Quality at the auction house is one example of a program with potential to achieve enhanced produce safety awareness and GAP compliance from a population of farmers who would otherwise prefer to remain separate.

\section{References}

Atman, C. J., Bostrom, A., Fischhoff, B., \& Morgan, M. G. (1994). Designing risk communications: Completing and correcting mental models of hazardous processes, part 1. Risk. Analysis, 14(5), 779-788. http://dx.doi.org/10.1111/j.15396924.1994.tb00289.x

Barinas, M., Doohan, D., Downer, R., Kleinschmidt, A., Kneen, H., \& Kline, T. (2010). Food safety for fruits and vegetables (Ohio State University Extension Fact Sheet No. ANR-25-10). Retrieved from http://ohioline.osu.edu/factsheet/ANR-25

Bell, S., \& McAllister, J. (2012). Sustainable agriculture through sustainable learning: Improving educational outcomes with best practices for adult learning. Burlington, Vermont: Northeast Sustainable Agriculture Research and Education (SARE). Retrieved from http://extension.unh.edu/resources/resource/326 $0 /$ Sustainable Agriculture through Sustainable Le arning:_Improving_educational_outcomes_with_ best practices for adult learning

Bender, M. H. (2003). Animal production and farm size in Holmes County, Ohio, and US agriculture. American Journal of Alternative Agriculture, 18(2), 70-79. http://dx.doi.org/10.1079/AJAA200236

Bostrom, A., Fischhoff, B., \& Morgan, M. G. (1992). Characterizing mental models of hazardous processes: A methodology and an application to radon. Journal of Social Issues, 48(4), 85-100. http://dx.doi.org/10.1111/j.1540-4560.1992. tb01946.x

Brown, L. (1981). Innovation diffusion: A new perspective. New York: Methuen.

Donnermeyer, J. F., Anderson, C., \& Cooksey, E. C. (2013). The Amish population: County estimates and settlement patterns. Journal of Amish and Plain Anabaptist Studies, 1(1), 72-109. http://kb.osu.edu/dspace/handle/1811/54889
Fischhoff, B., Bostrom, A., \& Quadrel, M. J. (1997). Risk perception and communication. In R. Detels, J. McEwen, \& G. Omenn (Eds.), Oxford textbook of public health (pp. 987-1002). London: Oxford University Press.

Greenfield Farms. (n.d.). Certified Organic Products | Greenfield Farms. Retrieved May 19, 2016, from http://www.gffarms.com/

Guest, G., Bunce, A., \& Johnson, L. (2006). How many interviews are enough? An experiment with data saturation and variability. Field Methods, 18(1), 5982. http://dx.doi.org/10.1177/1525822X05279903

Hansen, J., L. Holm, L. Frewer, P. Robinson, P. Sandøe. 2003 Beyond the knowledge deficit: recent research into lay and expert attitudes to food risks. Appetite 41, 111-121.

Hoorman, J. H., \& Spencer, E. A. (2001). Engagement and outreach with Amish audiences. Journal of Higher Education Outreach and Engagement, 7(1\&2), 157-168. http://openjournals.libs.uga.edu/index.php/jheoe/ article/view/222

Johnson-Laird, P. N. (1983). Mental models: Toward a cognitive science of language, inference and consciousness. Cambridge, Massachusetts: Harvard University Press.

Kline, D. (1990). Great possessions: An Amish farmer's journal. San Francisco: North Point Press.

Kline, T., Keen, H., Barrett, E., Kleinschmidt, A., \& Doohan, D. (2012). Adapting extension food safety programming for vegetable growers to accommodate differences in ethnicity, farming scale, and other individual factors. Journal of Extension, 50(1), Article 1IAW1. http://www.joe.org/joe/2012february/iw1.php

Landing, J. E. (1970). Amish settlement in North America: A geographic brief. Bulletin of the Illinois Geographical Society, 12, 65-69.

Lengacher, B., Kline, T., Harpster, L., Williams, M., \& LeJeune, J. (2010). Low prevalence of Escherichia coli O157:H7 in horses in Ohio, USA. Journal of Food Protection, 11(4), 2089-2092. http://www.food protection.org/publications/journal-of-foodprotection/

Long, S. (2003). The complexity of labor exchange among Amish farm households in Holmes County, Ohio (Unpublished doctoral dissertation). Columbus: Ohio State University. 
Lowry, S., \& Noble, A. G. (2000). The changing occupational structure of the Amish of the Holmes County, Ohio, Settlement. The Great Lakes Geographer, 7(1), 26-37. http://www.geography. uwo.ca/research/the great lakes geographer

Macias, T., \& Williams, K. (2015). Know your neighbors, save the planet: Social capital and the widening wedge of pro-environmental outcomes. Environment and Behavior, 48(3), 391-420. http://dx.doi.org/10.1177/0013916514540458

Moore, R. H. (1995). Sustainability and the Amish: Chasing butterflies? Culture and Agriculture, 16(53), 24-25. http://dx.doi.org/10.1525/cuag.1995.16.53.24

Moore, R., Stinner, D. H., Kline, D., \& Kline, E. (2000). Honoring creation and tending the garden: Amish views of biodiversity. In D. Posey (Ed.), Cultural and spiritual values of biodiversity (pp. 305-309). London: Intermediate Technology Publications.

Morgan, M. G., B. Fischoff, A. Bostyrom, and C.J. Atman. (2002). Risk communication: A mental models approach. Cambridge University Press, Cambridge, United Kingdom.

Mount Hope Auction House. (n.d.). Growers' Code of Excellence [Flyer]. Mount Hope, Ohio: Mount Hope Auction House. Copy in possession of author.

Netting, R. (1993). Smallholders, householders: Farm families and the ecology of intensive, sustainable agriculture. Redwood City, California: Stanford University Press.

Parker, J. (2006). Land tenure in the Sugar Creek watershed: A contextual analysis of land tenure and social networks, intergenerational farm succession, and conservation use among Anabaptist farmers of Wayne County, Obio (Unpublished doctoral dissertation). The Ohio State University, Columbus. Retrieved from http://rave.ohiolink.edu/etdc/view?acc_num $=$ osu $\underline{1147971583}$

Parker, J. S. (2013). Integrating culture and community into environmental policy: Balancing the benefits of agency and locally led watershed management and decision making. Agriculture and Human V alues, 30(2), 159-178. http://dx.doi.org/10.1007/s10460012-9392-8
Parker, J. S., Wilson, R. S., LeJeune, J. T., Rivers III, L., \& Doohan, D. (2012a). An expert guide to understanding grower decisions related to fresh fruit and vegetable contamination prevention and control. Food Control, 26(1), 107-116. http://dx.doi.org/10.1016/j.foodcont.2011.12.025

Parker, J. S., Wilson, R. S., LeJeune, J. T., \& Doohan, D. (2012b). Including growers in the "food safety" conversation: Enhancing the design and implementation of food safety programming based on farm and marketing needs of fresh fruit and vegetable producers. Agriculture and Human V alues, 29(3), 303-319. http://dx.doi.org/10.1007/s10460012-9360-3

Salamon, S., Farnsworth, R. L., \& Rendziak, J. A. (1998). Is locally led conservation planning working? A farm town case study. Rural Sociology, 63(2), 214-234. http://dx.doi.org/10.1111/j.15490831.1998.tb00672.x

Sheils, C. M. (2002). What does the term "new farmer" mean? (Professional Development Discussion Series No. 101). Retrieved from the New England Small Farm Institute website: http://www.smallfarm.org/

U.S. Department of Agriculture. (2009, October 6). Leafy green vegetables handled in the United States; Hearing on proposed marketing agreement no. 970. Public Hearing Docket \#AO-FE-09-0138 AMSFV-09-0029. Columbus, Ohio. Retrieved from http://federalregister.gov/a/E9-21295

Webster, K., Jardine, C., Cash, S.B., \& McMullen, L.M. (2010). Risk ranking: Investigating expert and public differences in evaluating food safety hazards. Journal of Food Protection, 73(10), 1875-1885.

Wejnert, B.. (2002). Integrating models of diffusion of innovations: A conceptual framework. Annual Review of Sociology, 28, 297-326. http://dx.doi.org/ 10.1146/annurev.soc.28.110601.141051

Yoder, R. (2009). Testimony given at the "Leafy green vegetables handled in the United States; Hearing on proposed marketing agreement." Columbus, Ohio. Retrieved from http://www.regulations.gov/ \#!documentDetail;D=AMS-FV-09-0029-0071 